\title{
Contextual Effect of the Community Health Center on the Use of Antenatal Care: A Multilevel Analysis Evidence from Semarang, Central Java
}

\author{
Widyawati'), Eti Poncorini Pamungkasari²), Bhisma Murti1) \\ ${ }^{1)}$ Masters Program in Public Health, Universitas Sebelas Maret \\ 2)Faculty of Medicine, Universitas Sebelas Maret
}

\section{ABSTRACT}

Background: The completeness of antenatal care is an effort to reduce prenatal mortality. This study aimed to analyze the contextual effect of the community health center on the use of antenatal care.

Subjects and Method: This study was an analytical observational study with a cross-sectional approach. This study was conducted from June to August 2020. The sample consisted of 250 study subjects that were selected by simple random sampling. The dependent variable was antenatal care. The independent variables were husband support, knowledge, attitude, antenatal information, self-efficacy, cues to action, perceived seriousness, perceived susceptibility, perceived benefits, perceived barriers, and complete facilities. This study used questionnaires to collect the data with multilevel analysis through a logistic regression approach in STATA 13.

Results: Complete antenatal care visits increased with strong support $(\mathrm{b}=4.36 ; 95 \% \mathrm{CI}=0.92$ to $7.81 ; \mathrm{p}=0.013)$, high knowledge $(\mathrm{b}=3.59 ; 95 \%$ $\mathrm{CI}=0.67$ to $6.51 ; \mathrm{p}=0.016)$, positive attitude $(\mathrm{b}=$ 4.07; $95 \% \mathrm{CI}=0.65$ to $7.50 ; \mathrm{p}=0.020$ ), much antenatal information $(\mathrm{b}=4.20 ; 95 \% \mathrm{CI}=0.94$ to $7.46 ; p=0.012)$, high self-efficacy $(b=3.05 ; 95 \%$ $\mathrm{CI}=0.20$ to $5.90 ; \mathrm{p}=0.036)$, high cues to action Cite this as:

Widyawati, Pamungkasari EP, Murti B (2020). Contextual Effect of the Community Health Center on the Use of Antenatal Care: A Multilevel Analysis Evidence from Semarang, Central Java. J Matern Child Health. 05(06): 663-672. https://doi.org/10.26911/thejmch.2020.05.06.06.

cc (i) (2) Journal of Maternal and Child Health is licensed under a Creative Commons Attribution-Non Commercial-Share Alike 4.0 International License.

\section{BACKGROUND}

The Indonesian government has been implementing breakthroughs to accelerate the reduction of the Maternal Mortality Rate (MM$\mathrm{R})$, including the Safe Motherhood program, which is known as the 4 pillar concept, name- $(\mathrm{b}=3.41 ; 95 \% \mathrm{CI}=0.62$ to $6.20 ; \mathrm{p}=0.017)$, high perceived seriousness $(\mathrm{b}=4.48 ; 95 \% \mathrm{CI}=1.20$ to 7.76; $\mathrm{p}=0.007)$, high perceived susceptibility $(\mathrm{b}=$ $3.35 ; 95 \% \mathrm{CI}=0.31$ to $6.38 ; \mathrm{p}=0.031)$, high perceived benefit $(\mathrm{b}=3.82 ; 95 \% \mathrm{CI}=0.49$ to 7.16 ; $\mathrm{p}=0.025)$, high perceived barrier $(\mathrm{b}=-3.13 ; 95 \%$ $\mathrm{CI}=-6.10$ to $-0.16 ; \mathrm{p}=0.039$ ), and complete facilities $(b=4.97 ; 95 \% \mathrm{CI}=0.59$ to $9.34 ; \mathrm{p}=0.026)$. The variation at the community health center level showed a contextual effect on antenatal care with an intraclass correlation (ICC) $=51.09 \%$. Conclusion: Complete antenatal care is affected by husband support, knowledge, attitude, antenatal information, self-efficacy, cues to action, perceived seriousness, perceived susceptibility, perceived benefits, perceived barriers, complete facilities, and community health center.

Keywords: Antenatal care, community health center, multilevel analysis

\section{Correspondence:}

Widyawati. Masters Program in Public Health, Universitas Sebelas Maret. Jl. Ir. Sutami 36A, Surakarta 57126, Central Java. Email: widyawatichin1412@gmail.com. Mobile: +6285742919076. ly family planning, antenatal care, clean and safe delivery, and postpartum management. Antenatal care is one of the basics of maternal care. It plays an important role in delivery preparation. It aimed to provide room for improvement (Gottfredsdottir et al., 2016). Efforts are made for pregnant women 
to receive preventive services that meet quality standards (Central Java Health Office, 2018).

Maternal health care must meet the minimum frequency in each trimester: once in the first trimester (o to 12 weeks of gestational age), once in the second trimester (12 to 24 weeks of gestational age), and twice in the third trimester (gestational age at 24 weeks until delivery). Services for the implementation of health care for pregnant women can be done by looking at the $\mathrm{K}_{1}$ and $\mathrm{K}_{4}$ coverage. K1 coverage (first visit) in Central Java in 2018 was $99.63 \%$ and K4 coverage was 93.07\%, while in Semarang Regency K1 coverage was $100 \%$ and $\mathrm{K}_{4}$ coverage was 89.12\% (Central Java Health Office, 2018). Poor Antenatal Care Visits (ANC) in pregnant women will increase the incidence of postpartum hemorrhage. However, regular ANC can detect the possible disease occurs during pregnancy so that it can be treated immediately (Nyfløt et al., 2017).

According to a study conducted by Uldbjerg et al. (2020), the main barriers to the use of ANC that could be identified were unqualified services including poor behavior of health care personnel, socio-cultural practices that were not successfully harmonized with ANC, and low support from the husbands including difficulties in encouraging them to attend ANC. Poor knowledge and maternal attitudes of ANC will affect ANC visit practices.

Dowswell et al. (2015) stated that poor ANC visits could increase perinatal mortality. Affordable and quality ANC could be an effective strategy to reduce the incidence of Low Birth Weight (LBW) (Paul, Zaveri, and Chouhan, 2019). The results of this study indicated that quality and complete ANC that met the standards was important to determine health development and prevention of risks during delivery.
Based on the background description, the authors were interested in studying and observing more about the analysis of the contextual effect of the community health centers on the complete utilization of antenatal care.

\section{SUBJECTS AND METHOD}

\section{Study Design}

This study was an analytical observational study with a cross sectional approach. This study was conducted in Semarang Regency, Central Java, from June to August 2020.

\section{Population and Sample}

The population of this study was all pregnant women in Semarang Regency. The sample consisted of 250 study subjects that were selected by simple random sampling.

\section{Study Variables}

The dependent variable was antenatal care. The independent variables were husband support, maternal knowledge, maternal attitude, antenatal information that health care personnel had, self-efficacy, cues to action, perceived seriousness, perceived susceptibility, perceived benefits, perceived barriers, complete facilities, and community health center.

\section{Operational Definition of Variables} Antenatal care was the service of health care personnel to pregnant women from conception to delivery, measured by a questionnaire.

Husband support was assistance from the husband received by the mother (emotional support, appreciation, instrumental, and informational) in conducting antenatal care visits, measured by a questionnaire.

Maternal knowledge was all things that were known about the meaning, purpose, benefits, and ANC visits, measured by a questionnaire.

Maternal attitude was a response in the form of a positive or negative assessment that 
affected the mother in doing antenatal visits, measured by a questionnaire.

Antenatal information was data on antenatal care that were managed and delivered by health care personnel to improve antenatal visits, measured by a questionnaire.

Self-efficacy was the belief that the mother was able to do behaviors that could affect the use of antenatal care, measured by a questionnaire.

Cues to action were the stimuli needed to encourage decision making in order to provide complete antenatal care, measured by a questionnaire.

Perceived seriousness was the mother's perception of her beliefs about the dangers of not doing antenatal checked up, measured by a questionnaire.

Perceived susceptibility was the mother's perception of a condition that was susceptible to disease during pregnancy so that it was necessary to carry out an antenatal checked up, measured by a questionnaire.

Perceived benefit was the mother's perception to assess the advantages or benefits of the results of doing antenatal checked up, measured by a questionnaire.

Perceived barriers were the mother's perception of barriers during antenatal checked up, measured by a questionnaire.

Completeness of facilities was the facilities and infrastructure required for antenatal care, measured by a questionnaire.

Community health center was a variable located at the community health center level that could affect antenatal completeness, measured by a questionnaire.

\section{Data Analysis}

Univariate analysis aimed to see the frequency distribution and the percentage of the characteristics of the study subjects. Bivariate analysis aimed to study the relationship between antenatal care and independent variables using Chi-square. Multivariate analysis used multilevel STATA.

\section{Research Ethic}

Research ethics included informed consent, anonymity, confidentiality, and ethical clearance. The ethical clearance was carried out at Dr. Moewardi Hospital on January 16, 2020. Number: 068/I/HREC/2020.

\section{RESULTS}

\section{Sample Characteristics}

There were 250 pregnant women in Semarang Regency as the study subjects. The frequency distribution of the characteristics of the study subjects showed that most of the mothers aged $\geq 28$ years were 152 subjects (60.8\%). Half of the study subjects who had $<$ Senior High School education were 125 subjects (50.0\%) and $\geq$ Senior High School education were 125 subjects (50.0\%). There were 130 subjects (52.0\%) who had a family income by $\geq$ Rp.2,0550.00.

The last characteristic was financing status. There were 131 subjects (52.4\%) who had general financing status (cash and private insurance).

Bivariate analysis aimed to see the relationship between independent variables (husband support, maternal knowledge, maternal attitude, antenatal information, selfefficacy, cues to action, perceived seriousness, perceived susceptibility, perceived benefits, perceived barriers, completeness of facilities, and community health centers) and the dependent variable (antenatal care). The results of the bivariate analysis with the Chisquare test were as follows:

Strong husband support $(\mathrm{OR}=4.21 ; \mathrm{p}$ $<0.001$ ), high maternal knowledge (OR= 19.27; $\mathrm{p}<0.001)$, positive attitude $(\mathrm{OR}=$ 15.94; $\mathrm{p}<0.001)$, high ANC information $(\mathrm{OR}=$ $5.15 ; \mathrm{p}<0.001)$, strong self-efficacy ( $\mathrm{OR}=$ 5.44 ; $\mathrm{p}<0.001)$, high cues to action $(\mathrm{OR}=$ 4.73; $\mathrm{p}<0.001)$, high perceived seriousness $(\mathrm{OR}=11.56 ; \mathrm{p}<0.001)$, high perceived susceptibility $(\mathrm{OR}=17.24 ; \mathrm{p}<0.001)$, high perceived benefit (OR: 2.58; p <0.001), high 
Widyawati et al./ Contextual Effect of the Community Health Center on the Use of ANC

perceived barrier $(\mathrm{OR}=0.22 ; \mathrm{p}<0.001)$, and complete health facilities $(\mathrm{OR}=2.25 ; \mathrm{p}=$ o.011) increased good antenatal care $\geq 4$ times.

Table 1. The Characteristics of the Study Subject

\begin{tabular}{lcc}
\hline \multicolumn{1}{c}{ Characteristic } & Frequency (n) & Percentage (\%) \\
\hline Age & & \\
$<28$ years & 98 & 39.2 \\
$\geq 28$ years & 152 & 60.8 \\
Education & & \\
< Senior High School & 125 & 50.0 \\
Z Senior High School & 125 & 50.0 \\
Family Income & & \\
< Rp. 2,055,000 & 120 & 48.0 \\
$\geq$ Rp. 2,O55,O0O & 130 & 52.0 \\
Financing Status & & \\
General (cash, private insurance) & 131 & 52.4 \\
National health insurance (PBI, non-PBI) & 119 & 47.6 \\
\hline
\end{tabular}

2. The result of bivariate analysis

Table 2. Bivariate analysis

\begin{tabular}{|c|c|c|c|c|c|c|c|c|c|}
\hline \multirow{3}{*}{$\begin{array}{l}\text { Independent } \\
\text { Variable }\end{array}$} & & \multicolumn{4}{|c|}{ Antenatal Care } & \multirow{2}{*}{\multicolumn{2}{|c|}{ Total }} & \multirow{3}{*}{ OR } & \multirow{3}{*}{$\mathbf{p}$} \\
\hline & & \multicolumn{2}{|c|}{$<4$ times } & \multicolumn{2}{|c|}{$\geq 4$ times } & & & & \\
\hline & & $\mathbf{N}$ & $\%$ & $\mathbf{N}$ & $\%$ & $\mathbf{N}$ & $\%$ & & \\
\hline \multirow{4}{*}{$\begin{array}{l}\text { Husband } \\
\text { support } \\
\text { Knowledge }\end{array}$} & Weak & 69 & 63.3 & 40 & 36.7 & 109 & 100 & \multirow[t]{2}{*}{4.21} & \multirow{2}{*}{$<0.001$} \\
\hline & Strong & 41 & 29.1 & 100 & 70.9 & 141 & 100 & & \\
\hline & Low & 85 & 80.2 & 21 & 19.8 & 106 & 100 & \multirow[t]{2}{*}{19.27} & \multirow[t]{2}{*}{$<0.001$} \\
\hline & High & 25 & 17.4 & 119 & 82.6 & 144 & 100 & & \\
\hline \multirow[t]{2}{*}{ Attitude } & Negative & 92 & 73.0 & 34 & 27.0 & 126 & 100 & \multirow[t]{2}{*}{$15 \cdot 94$} & \multirow[t]{2}{*}{$<0.001$} \\
\hline & Positi & 18 & 14.5 & 106 & 85.5 & 124 & 100 & & \\
\hline \multirow{4}{*}{$\begin{array}{l}\text { Antenatal } \\
\text { information } \\
\text { Self-efficacy }\end{array}$} & Little & 78 & 63.4 & 45 & 36.6 & 123 & 100 & \multirow[t]{2}{*}{5.15} & \multirow[t]{2}{*}{$<0.001$} \\
\hline & Much & 32 & 25.2 & 95 & 74.8 & 127 & 100 & & \\
\hline & Weak & 82 & 62.6 & 49 & 37.4 & 131 & 100 & \multirow[t]{2}{*}{5.44} & \multirow[t]{2}{*}{$<0.001$} \\
\hline & Strong & 28 & 23.5 & 91 & 76.5 & 119 & 100 & & \\
\hline \multirow[t]{2}{*}{ Cues to action } & Low & 79 & 61.7 & 49 & 38.3 & 128 & 100 & \multirow[t]{2}{*}{$4 \cdot 73$} & \multirow[t]{2}{*}{$<0.001$} \\
\hline & High & 31 & 25.4 & 91 & 74.6 & 122 & 100 & & \\
\hline \multirow{2}{*}{$\begin{array}{l}\text { Perceived } \\
\text { seriousness }\end{array}$} & Low & 88 & 71.0 & 36 & 29.0 & 124 & 100 & \multirow[t]{2}{*}{11.56} & \multirow[t]{2}{*}{$<0.001$} \\
\hline & High & 22 & 17.5 & 104 & 82.5 & 126 & 100 & & \\
\hline \multirow{4}{*}{$\begin{array}{l}\text { Perceived } \\
\text { susceptibility } \\
\text { Perceived } \\
\text { benefits }\end{array}$} & Low & 98 & 68.5 & 45 & 31.5 & 143 & 100 & \multirow[t]{2}{*}{17.24} & \multirow[t]{2}{*}{$<0.001$} \\
\hline & High & 12 & 11.2 & 95 & 88.8 & 107 & 100 & & \\
\hline & Low & 64 & 56.6 & 49 & 43.4 & 113 & 100 & \multirow[t]{2}{*}{2.58} & \multirow[t]{2}{*}{$<0.001$} \\
\hline & High & 46 & 33.6 & 91 & 66.4 & 137 & 100 & & \\
\hline Perceived & Low & 35 & 26.9 & 95 & 73.1 & 130 & 100 & \multirow[t]{2}{*}{0.22} & $<0.001$ \\
\hline barriers & High & 75 & 62.5 & 45 & 37.5 & 120 & 100 & & \\
\hline Complete & Incomplete & 30 & 60.0 & 20 & 40.0 & 50 & 100 & 2.25 & 0.011 \\
\hline facilities & Complete & 80 & 40.0 & 120 & 60.0 & 200 & 100 & & \\
\hline
\end{tabular}


Widyawati et al./ Contextual Effect of the Community Health Center on the Use of ANC

3. The result of multilevel analysis

Table 3 The result of multilevel analysis

\begin{tabular}{|c|c|c|c|c|}
\hline \multirow[b]{2}{*}{ Independent Variable } & \multirow[b]{2}{*}{ b } & \multicolumn{2}{|c|}{$95 \%$ CI } & \multirow[b]{2}{*}{$\mathbf{p}$} \\
\hline & & $\begin{array}{c}\text { Lower } \\
\text { Limit }\end{array}$ & $\begin{array}{l}\text { Upper } \\
\text { Limit }\end{array}$ & \\
\hline \multicolumn{5}{|l|}{ Fixed Effect } \\
\hline Husband support (strong) & 4.36 & 0.92 & 7.81 & 0.013 \\
\hline Knowledge (high) & 3.59 & 0.67 & 6.51 & 0.016 \\
\hline Attitude (positive) & 4.07 & 0.65 & $7 \cdot 50$ & 0.020 \\
\hline Antenatal information (much) & 4.20 & 0.94 & 7.46 & 0.012 \\
\hline Self-efficacy (strong) & 3.05 & 0.20 & 5.90 & 0.036 \\
\hline Cues to action (high) & 3.41 & 0.62 & 6.20 & 0.017 \\
\hline Perceived seriousness (high) & 4.48 & 1.20 & 7.76 & 0.007 \\
\hline Perceived susceptibility (high) & $3 \cdot 35$ & 0.31 & 6.38 & 0.031 \\
\hline Perceived benefits (high) & 3.82 & 0.49 & 7.16 & 0.025 \\
\hline Perceived barrier (high) & -3.13 & -6.10 & -0.16 & 0.039 \\
\hline Completeness of facilities (complete) & 4.97 & 0.59 & 9.34 & 0.026 \\
\hline \multicolumn{5}{|l|}{ Random Effect } \\
\hline \multicolumn{5}{|l|}{ Community health center } \\
\hline Var (constant) & 3.44 & & 3.98 & 29.68 \\
\hline $\mathrm{N}$ observation $=250$ & & & & \\
\hline Log likelihood = -22.17 & & & & \\
\hline LR test vs. logistic regression, $p=0.005$ & & & & \\
\hline $\mathrm{ICC}=51.09 \%$ & & & & \\
\hline
\end{tabular}

Pregnant women with strong husband support had a logodd of 4.36 times for doing antenatal care by $\geq 4$ compared to pregnant women who had low husband support $(\mathrm{b}=$ 4.36; $95 \% \mathrm{CI}=0.92$ to $7.81 ; \mathrm{p}=0.013$ ). Pregnant women with a high knowledge had a logodd of 3.59 times for doing antenatal care by $\geq 4$ compared to pregnant women with low knowledge $(b=3.59 ; 95 \% \mathrm{CI}=0.67$ to 6.51 ; $\mathrm{p}=$ 0.016). Pregnant women with positive attitudes had a logodd of 4.07 times for doing antenatal care by $\geq 4$ compared to pregnant women with negative attitudes $(b=4.07 ; 95 \%$ $\mathrm{CI}=0.65$ to $7.50 ; \mathrm{p}=0.020$ ). Pregnant women with much antenatal information had a logodd of 4.20 times for doing antenatal care by $\geq 4$ compared to pregnant women who had little antenatal information $(b=4.20 ; 95 \%$ $\mathrm{CI}=0.94$ to $7.46 ; \mathrm{p}=0.012$ ). Pregnant women with a strong self-efficacy had a logodd of 3.05 times for doing antenatal care by $\geq 4$ compared to pregnant women with a weak self-efficacy (b=3.05; 95\% CI= 0.20 to 5.90 ; $\mathrm{p}=0.036)$. Pregnant women with high cues to action had a logodd of 3.41 times for doing antenatal care by $\geq 4$ compared to pregnant women who had low cues to action $(b=3.41$; 95\% CI= 0.62 to $6.20 ; \mathrm{p}=0.017$ ).

Pregnant women with a high perceived seriousness had a logodd of 4.48 times for doing antenatal care by $\geq 4$ compared to pregnant women with low perceived seriousness $(b=4.48 ; 95 \% \mathrm{CI}=1.20$ to $7.76 ; \mathrm{p}=0.007)$. Pregnant women with a high perceived susceptibility had a logodd of 3.35 times for doing antenatal care by $\geq 4$ compared to pregnant women with a low perceived susceptibility $(\mathrm{b}=3.35 ; 95 \% \mathrm{CI}=0.31$ to 6.38 ; $\mathrm{p}=$ o.031). Pregnant women with high perceived benefits had a logodd of 3.82 times for doing antenatal care by $\geq 4$ compared to pregnant women who had low perceived benefits $(b=$ 3.82 ; 95\% CI= 0.49 to 7.16 ; $\mathrm{p}=0.025)$. Pregnant women with high perceived barriers had a logodd of -3.13 times for doing antenatal care by $\geq 4$ compared to pregnant women 
Widyawati et al./ Contextual Effect of the Community Health Center on the Use of ANC

with low perceived barriers $(b=-3.13 ; 95 \%$ $\mathrm{CI}=-6.10$ to $-0.16 ; \mathrm{p}=0.039)$. Pregnant women with complete facilities had a logodd of 4.97 times for doing antenatal care by $\geq 4$ compared to pregnant women who had incomplete facilities $(b=4.97 ; 95 \% \mathrm{CI}=0.59$ to 9.34; $\mathrm{p}=0.026$ ). The multilevel result showed that ICC $=51.09 \%$. It showed that $51.09 \%$ of the variation in antenatal care was determined by the community health center.

\section{DISCUSSION}

\section{The effect of husband support on the complete utilization of ANC}

The result showed that there was an effect of husband support on the complete utilization of antenatal care. Hanifah, Pratomo, and Hoang (2018) stated that husband support had a positive effect on the antenatal visit. The result is in line with a study conducted by Agampodi et al. (2017) that strong husband support increased the completeness of antenatal care. According to Motlagh et al. (2017), the husband's involvement in prenatal care could reduce pregnancy anxiety and improve the quality of life of pregnant women.

\section{The effect of maternal knowledge on the complete utilization of ANC}

The result showed that there was an effect of maternal knowledge on the complete utilization of antenatal services. According to Haddad et al. (2016), pregnant women who conducted antenatal care by $\geq 4$ times had higher knowledge than pregnant women who had few antenatal care. Sinyange et al. (2016) stated that the low knowledge of pregnant women about the importance of early pregnancy visits reduced complete antenatal care.

Kaswa, Rupesinghe, and Longo-Mbenza (2018) explained that one of the factors affecting the postpone in doing antenatal care was the lack of maternal knowledge about the benefits of antenatal care for primigravida mothers.

\section{The effect of maternal attitude on the complete utilization of ANC}

The result showed that there was an effect of maternal attitude on the complete utilization of antenatal care. Aritonang et al. (2019) showed that $56.0 \%$ of pregnant women had a negative attitude towards antenatal care. Ogu and Alegbeleye (2018) explained that pregnancy and delivery were holistic experiences that were affected by the attitude and care received. Poor attitude of pregnant women occurred because pregnant women only made antenatal visits if they were sick or felt that they just need to be checked, as well as the presumption of antenatal visits that were not related to the prevention of maternal and infant mortality (Tasliah, Widagdo, and Nugraha, 2017).

\section{The effect of information on the complete utilization of ANC}

The results showed that there was an effect of information of health care personnel on the complete utilization of antenatal care. Ewunetie et al. (2018) explained that information could improve the completeness of antenatal care. Pregnant women were late in checking their pregnancies due to a lack of information about pregnancy care (Desta et al., 2019). This is in line with Zhou et al. (2018) that information about antenatal care affected pregnancy care management and reduced maternal anxiety.

\section{The effect of self-efficacy on the complete utilization of antenatal care}

The result showed that there was an effect of self-efficacy on the complete utilization of antenatal care. Sulaeman (2016) explained that the Health Belief Model theory could be used for assessing self-efficacy. Tsai et al. (2018) stated that self-efficacy enabled individuals to master and deal with events during pregnancy. Izadirad et al. (2017) showed that selfefficacy affected the use of antenatal care. 
Positive self-efficacy played an important role in a mother's adaptability to pregnancy.

\section{The effect of cues to action on the complete utilization of ANC}

The results showed that there was an effect of cues to action on the complete utilization of antenatal care. Cues to action were the stimulus needed to encourage the decision-making process. Cues to action were not only come from the external but also internal (Murti, 2018). According to Kahsay et al. (2019), cues to action were needed to motivate health behavior regarding the use of antenatal care.

7. The effect of perceived seriousness on the complete utilization of ANC

The result showed that there was an effect of perceived seriousness on the complete utilization of antenatal care. The Health Belief Model explains that a person with perceptions of serious illness and consequences may prevent or reduce the severity of the disease (Murti, 2018). Kahsay et al. (2019) stated that perceived seriousness affected the use of antenatal care. Tesfaye et al. (2017) stated that a high perceived susceptibility was related to pregnancy complications.

\section{The effect of perceived susceptibility on the complete utilization of ANC}

The result showed that there was an effect of perceived susceptibility on the complete utilization of antenatal care. Susceptibility was a strong perception in encouraging people to adopt healthy behaviors (Sulaeman, 2016).

Tesfaye et al. (2017) stated that high perceived susceptibility could improve antenatal care such as an abortion history. Kahsay et al. (2019) explained that high perceived susceptibility was related to the intention of pregnant women to use health facilities.

\section{The effect of perceived benefits on the complete utilization of ANC}

The result of this study indicated that there was an effect of perceived benefits on the complete utilization of antenatal care. Kaswa, Rupesinghe, and Longo-Mbenza (2018) ex- plained that the delay in antenatal care occurred due to low perceived benefits. Tekelab et al. (2019) explained that quality antenatal care balanced with the promotion of the benefits of using antenatal care through the mass media could increase perceived benefits about antenatal care by $\geq 4$.

\section{The effect of perceived barriers on the complete utilization of ANC}

The result showed that there was an effect of perceived barriers on the complete utilization of antenatal care. The Health Belief Model described a person who had the perception that a health problem could be life-threatening, and doing healthy behavior could reduce this threat (Murti, 2018). Nisingizwe et al. (2020) stated that perceived barriers reduced the use of antenatal care. According to Uldbjerg et al. (2020), perceived barriers occurred due to lack of resources at health centers, poor attitudes of health care personnel, mismatches among ANCs, age of young or old mothers, procedures at the community health center, mandatory HIV testing and checking up.

\section{The effect of complete facilities on the complete utilization of ANC}

The results showed that there was an effect of the completeness of the facilities on the complete utilization of antenatal care. Fekadu, Ambaw, and Kidanie (2019) showed that the completeness of health facilities affected the use of antenatal care. Boah, Mahama, and Ayamga (2018) also explained that incomplete antenatal care facilities caused pregnant women with complications to choose to visit the hospital for complete pregnancy checkup, thus reducing the use of antenatal care with incomplete health facilities.

\section{The effect of community health center on the complete utilization of ANC}

Based on the multilevel analysis, the ICC= $51.09 \%$. This indicator showed that the condition of the community health center at each 
stratum had an environmental effect on the variation of antenatal care by $51.09 \%$. Therefore, the environmental effect, namely the community health center, which was shown from the multilevel analysis were essential to note. Community health center carried out the main function, namely the first level of public health efforts, including maternal and child health (Minister of Health Regulation, 2016).

\section{AUTHOR CONTRIBUTION}

Widyawati was the main researcher who played a role in collecting and processing the data; Eti Poncorini Pamungkasari examined the conceptual framework and methodology of the study; Bhisma Murti examined the results of the study.

\section{CONFLICT OF INTEREST}

The researchers stated that there was no conflict of interest in this study.

\section{FUNDING AND SPONSORSHIP}

This study used personal funds from the main researcher.

\section{ACKNOWLEDGEMENT}

We would like to thank Eti Poncorini Pamungkasari and Bhisma Murti who reviewed this study. We thank the community health center in Semarang Regency and pregnant women who were willing to be the study subjects.

\section{REFERENCE}

Agampodi TC, Rheinländer T, Agampodi SB, Glozier N, Siribaddana N (2017). Social capital and health during pregnancy; An in depth exploration from rural Sri Lanka. Reprod Health, 14(1): 1-19. doi: 10.1186/s12978-017-0349-7.

Aritonang DVA, Adiwijaya S, Wulandari A, Anita N (2019). Related knowledge and support family mother pregnant wo- men attitudes about prenatal care (ANC). BirEx Journal, 1(3): 28-33. doi: 10.33258/birex.v1i3.340.

Boah M, Mahama AB, Ayamga EA (2018). They receive antenatal care in health facilities, yet do not deliver there: predicors of health facility delivery by women in rural Ghana. BMC Pregnancy Childbirth. 1-10. doi: 10.1186/s12884018-1749-6.

Desta M, Kassie B, Chanie H, Mulugeta H, Yirga T, Temesgen $\mathrm{H}$, et al. (2019). Adherence of iron and folic acid supplementation and determinants among pregnant women in Ethiopia: A systematic review and meta-analysis. Reprod Health, 16(1): 1-14. doi: 10.1186/s12978-019-0848-9.

Dinas kesehatan Kabupaten Semarang (2019). Profil kesehatan kabupaten Semarang.

Dinas Kesehatan Provinsi Jawa Tengah (2017). Profil kesehatan provinsi jawa tengah.

Dowswell T, Carroli G, Duley L, Gates S, Gülmezoglu AM, Khan-Neelofur D, et al. (2015). Alternative versus standard packages of antenatal care for low-risk pregnancy. WILEY. (7). doi:10.1002/14651858.CDooo934.pub3.

Ewunetie AA, Munea AM, Meselu BT, Simeneh MM, Meteku BT (2018). Delay on first antenatal care visit and its associated factors among pregnant women in public health facilities of Debre Markos town, North West Ethiopia. BMC Pregnancy Childbirth, 18(1): 1-8. doi: 10.1186/s12884-018-1748-7.

Fekadu GA, Ambaw F, Kidanie SA (2019). Facility delivery and postnatal care services use among mothers who attended four or more antenatal care visits in Ethiopia: further analysis of the 2016 demographic and health survey. BMC 
Widyawati et al./ Contextual Effect of the Community Health Center on the Use of ANC

Pregnancy Childbirth, 19: 64. doi: 10.1186/s12884-019-2216-8.

Haddad GS, DeJong J, Terreri N, Perin, Vaz L, Newby H, et al. (2016). Patterns and determinants of antenatal care utilization: Analysis of national survey data in seven countdown countries. J Glob Health. 6(1). doi: 10.7189/jogh.06.010404.

Hanifah A, Pratomo H, Hoang G (2018). Husband's support for their wives in antenatal care visit. Kesmas, 13(1): 816. doi: 10.21109/kesmas.v13i1.1565.

Izadirad $\mathrm{H}$, Niknami S, Zareban I, Hidarnia A (2017). Effects of social support and self-efficacy on maternal prenatal cares among the first-time pregnant women, Iranshahr. J Family Reprod Health, 11(2): 67-73. https://www.ncbi.nlm.nih.gov/pubmed/29282413.

Kahsay ZH, Hiluf MK, Shamie R, Tadesse Y, Bazzano AN (2019). Pregnant women's intentions to deliver at a health facility in the pastoralist communities of Afar , Ethiopia: An application of the Health Belief Model. Int J Environ Res Public Health. 16: 888. doi:10.3390/ijerph16050888.

Kaswa R, Rupesinghe GFD, Longo-Mbenza B (2018). Exploring the pregnant women's perspective of late booking of antenatal care services at Mbekweni Health Centre in Eastern Cape, South Africa. Afr J Prim Health Care Fam Med, 10(1): 1-9. doi: 10.4102/phcfm.v10i1.1300.

Motlagh ME, Torkestani F, Amiri HA, Rabiee SM, Radpooyan L, Shirvani SDN, et al. (2017). Iranian husbands' involvement in prenatal care, childbirth and postpartum: Viewpoints of the mothers. J. Babol Univ Medical Sci. 19(5): 23-31. doi: 10.22088/jbums.19.5.23.
Murti, B. (2018) Prinsip dan metode riset epidemiologi edisi keempat. Surakarta: Universitas Sebelas Maret.

Nyfløt LT., Sandven I., Pedersen BS., Pettersen S., Zirqi IA., Rosenberg M. et al. (2017) 'Risk factors for severe postpartum hemorrhage: A case-control study. BMC Pregnancy Childbirth, 17(1): 1-9. doi: 10.1186/s12884-0161217-O.

Ogu R. dan Alegbeleye JO. (2018). Improving maternal health:Women's attitude to antenatal care utilization is crucial. Clin Obstet Gynecol Reprod Med, 4(1): 1-3. doi: 10.15761/cogrm.1000209.

Paul P., Zaveri A., Chouhan P. (2019). Assessing the impact of antenatal care utilization on low birthweight in India: Analysis of the 2015-2016 National Family Health Survey. Child Youth Serv Rev, 106: 104459. doi:10.1016/j.-childyouth.2019.104459.

Permenkes (2016). Peraturan Menteri Kesehatan no. 44 tahun 2016.

Rehg PA., Krauss MJ., Spitznagel EL., Bommarito K., Madden T., Olsen MA. et al. (2016). Maternal age and risk of labor and delivery complications. Matern Child Health J, 19(6): 1202-1211. doi: 10.1007/s10995-014-1624-7.

Saptarini I dan Suparmi (2016). Antenatal care service utilization and completeness in Kebon Kalapa Village , Bogor City. Buletin Penelitian Kesehatan, 3(4): 6-9.

Shahry P, Kalhori SRN, Esfandiyari A (2016). A comparative study of perceived social support and self-efficacy among women with wanted and unwanted pregnancy original article. Int J Community Based Nurs Midwifery, 4(2): 176-185.

Sinyange N, Sitali L, Jacobs C, Musonda P, Michelo C (2016). Factors associated with late antenatal care booking: population based observations from the 
2007 Zambia demographic and health survey. Pan Afr. med, 25: 109. doi: 10.11604/pamj.2016.25.109.6873.

Sulaeman ES (2016). Promosi kesehatan: teori dan implementasi di Indonesia.

Tasliah, Widagdo L., Nugraha P. (2017). Faktor-faktor yang berhubungan dengan kunjungan antenatal care(anc) padaibu hamil di wilayah kerja Puskesmas Candilamakota Semarang. Jurnal Kesehatan Masyarakat (e-Journal), 5(3): 637-644.

Tekelab T, Chojenta C, Smith R, Loxton D (2019). Factors affecting utilization of antenatal care in Ethiopia: A systematic review and meta- analysis. Plos ONE, 14(4): e0214848.. https://dx.doi.org/10.1371\%2Fjournal.pone.0214848.

Tesfaye G, Loxton D, Chojenta C, Semahegn A, Smith R (2017). Delayed initiation of antenatal care and associated factors in Ethiopia: A systematic review and meta-analysis. Reprod Health, 14: 150. doi: 10.1186/s12978-017-04124.

Tsai Y, Hsu Y, Hou T, Chang CH (2018). Effects of a web-based antenatal care system on maternal stress and self- efficacy during pregnancy: A study in Taiwan. J Midwifery Wom Heal, 63(2): 205-213. doi: 10.1111/jmwh.12685.

Uldbjerg CS, Schramma S, Kaducub FO, Ovugac E, Sodemanna M (2020). Perceived barriers to utilization of antenatal care services in northern Uganda: A qualitative study. Sex Reprod Health, 23: 100464. doi: 10.1016/j.srhc.2019.100464 .

Warri D, George A (2020). Perceptions of pregnant women of reasons for late initiation of antenatal care: A qualitative interview study. BMC Pregnancy Childbirth, o: 1-12. doi: 10.1186/s12884-020-2746-0.

Zhou C, Zheng W, Yuan Q, Zhang B, Chen H, Wang W, et al. (2018). Associations between social capital and maternal depression: Results from a follow-up study in China. BMC Pregnancy Childbirth. 18(1): 1-9. doi: 10.1186/s12884018-1673-9. 